\title{
WHAT DO I CALL THIS BEATING
}

\author{
Neobie Gonzalez \\ Plural / De La Salle University-Manila \\ marianeobiegonzalez@gmail.com
}

\begin{abstract}
About the Author
Neobie Gonzalez is from Manila and is currently taking up her Master's degree in Creative Writing at De La Salle University. Her works have appeared in Vagabond City, Cha: An Asian Literary Journal, Broke Journal, Used Gavitrons, and New Slang. Her essay "Voices from the Village" won a Carlos Palanca Memorial Award for Literature in 2013. She is also co-editor of the online journal Plural (http://pluralprosejournal.com).
\end{abstract}


I am stuck inside a bathroom stall. The red door won't let me leave. My palms lean upon it and push, but it keeps its place and keeps me in, on this tiled floor, boxed with only the fewest of footsteps given and the insistence that I take them. But I don't. My palms lean and push, again, and my body follows, forcing its weight on the stubborn wood. The lock swings free on both its sides, while smudges on the edge of the door-frame tell me I'm not the first it has asked to stay, not the first it has seen listening for the creak of the rusty hinge. When I knock, my fist calls out to kindness. I wait for sounds from the other side, but what it gives me is another knock and someone, asking, "Will you come out now, please?" because for hours I'd refused. I was eleven, stubborn too, and had locked myself in the shower, wedged my body into a corner for this sudden lessness that I no longer know, having already lost it there. This was a place of water and flow, and I had the door shut solid behind me, had my fists cover up my face. Metaphors are made to shape us. We give ourselves to framing for a chance at form. I heard the question again, soon, the asking less patient, less still. I said no, again, wanting the cold of the tiles to crawl up my feet, to hear the ticking of the bathwater from faucet to pail. Time ran slow. Somewhere, a boat was being rocked to sleep. I was dizzy on my shoulders and down my spine, and I don't remember why that was, having forgotten what kept me there, having the sea in me swilled out. But I recall the blurring of that afternoon into some beginning, the green rug's slanting fur showing me the first soft waves of wanting to leave. I parted the shower curtains and stepped out of the room, through with all its damp offers. When I opened the door there was air again, pushed into me by the few loose breaths I took after I stumbled out and learned to savor flight, finding arms that brought me closer to something, like what it was to be born once, or taken. 


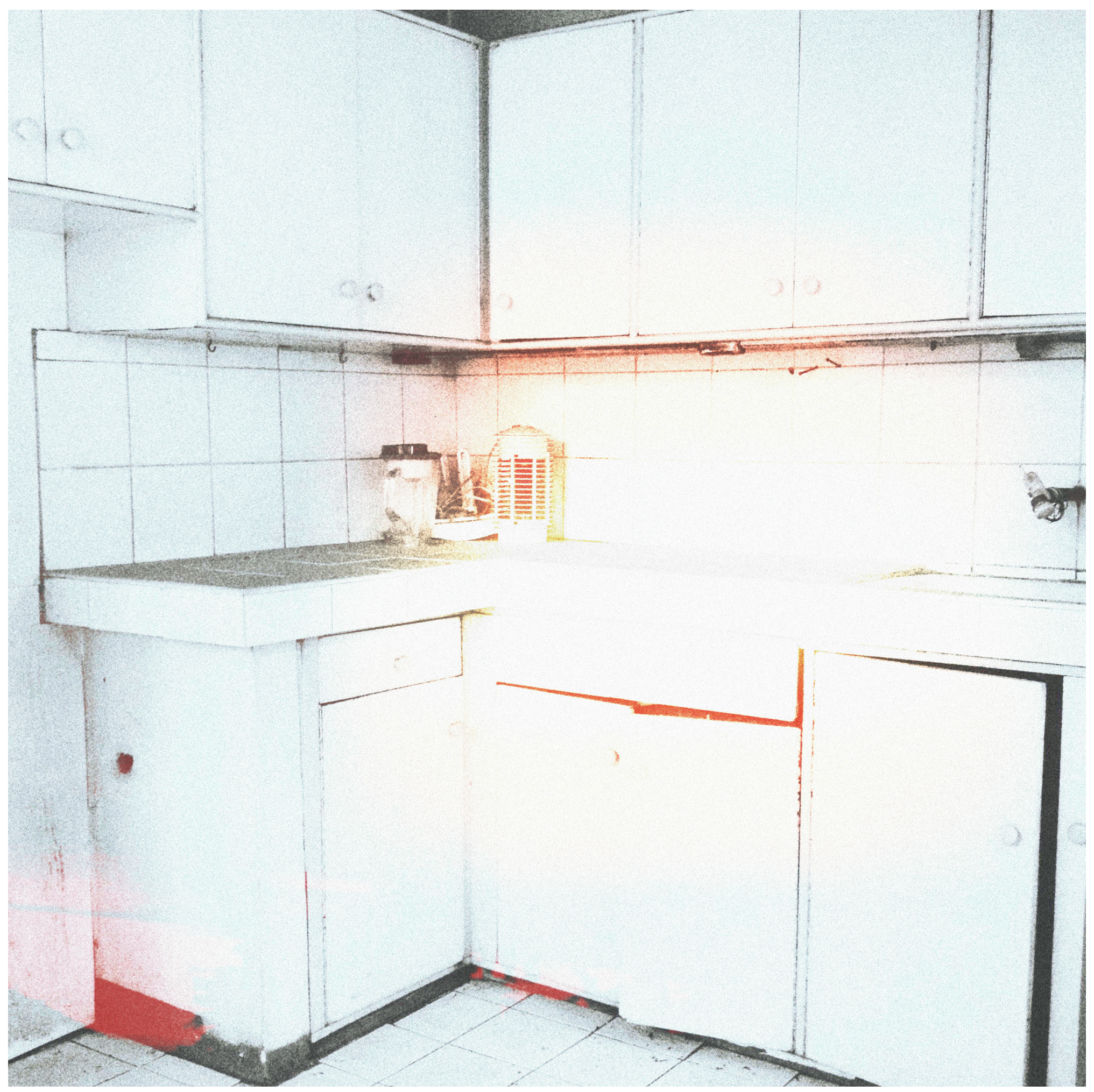

Kritika Kultura 26 (2016): -650

(ㄷ) Ateneo de Manila University

<http://kritikakultura.ateneo.net> 
a hum of white noise, the volume high, the words I'm reading in red and orange, my ribcage blasting, a restless city, my eyes fixed on the ceiling's fluorescent spills, my head pounding

My room is mostly white and mostly pink. My bed is covered with the image of tigers. My pillows are patterned with lilies. My body is filled with bees / my body is filled with something like bees: the murmurs of a crowd, sirens, Morse code, persistent and telling, but not telling enough.

a hum of white noise, the volume high, the words I'm reading in red and orange, my ribcage blasting, a restless city, my eyes shut to the ceiling's fluorescent spills, my fingers dancing, my fingers pausing, going, stopping

My cabinet is mostly white. It is split into two sections. On the bottom is a box of old notebooks. On top is a curtain of clothes. I step past them, sit on the shelf, close the door, stay.

a hum of white noise, the volume high, the words I've read in red and orange, my ribcage steadied, a city somewhere, my eyes open, my hands fists, my head down, my hair catching dust and my shoulders draped, a single sway of hems

My body is at rest. I sense that control is like putting out a fire. It is also not like putting out a fire, but like burning down a house. Flammable and inflammable mean the same thing. Belief and disbelief turn synonymous when we suspend them. We hold back as much as we can, and still, events happen at the same time though I write them in succession:

a hum, a hum, the volume down, the words left 


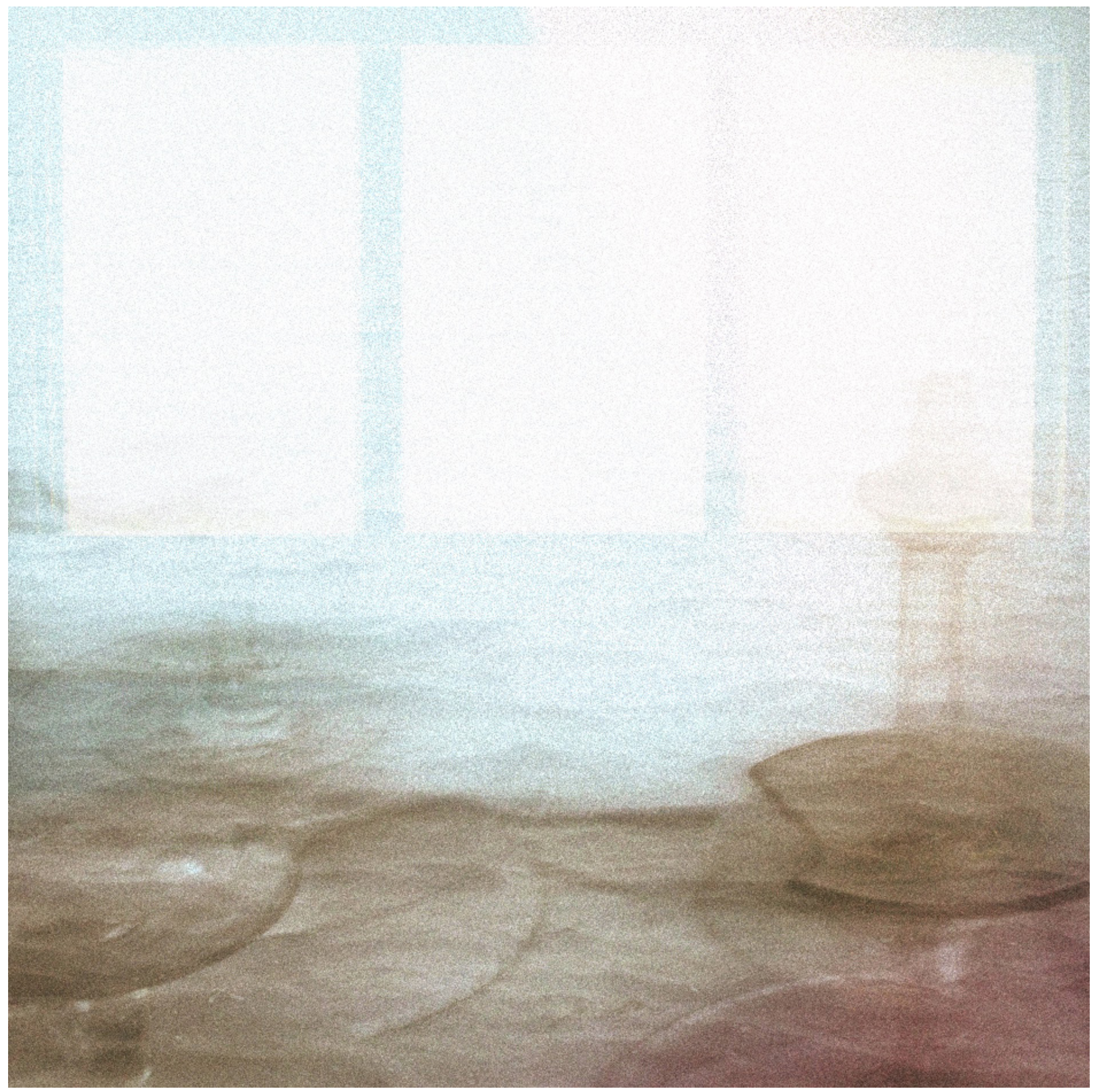

Kritika Kultura 26 (2016): -650

(ㄷ) Ateneo de Manila University

<http://kritikakultura.ateneo.net> 
We've been placing sheets of flypaper on the floor, leaving crumbs of food as bait. We patch up holes with rags, make trails of bread, lead the mice away from the homes they've built within ours. In another house, the traps are metal and rust. I spend an afternoon watching a rat caught in one of them. It runs from corner to corner, attempts to escape its cage. I ask if it could be set free on the street, but am told that it would be better off dead. We take these measures to protest its return, but return is a subjective notion when romanticized. When I take a second glance, I know that my eyes are trained to review what pleases. I think of how our attention is stirred by our desires. When the cage is brought to a nearby water pump, the rat revisits some past fear, its smallness shaking in anticipation of the cold. Trap and occupant are lowered into a bucket, yet in it, there is still space for air. The rat swims to the surface, holds up its head. The cage is lowered further. Pressure is applied until it is no longer necessary, the moment the bucket is at its most calm. I think of gestation, hands submerged in fluid, as if delivery was the next stage in the sequence, but what follows isn't life. The rat's eyes are open, so is its jaw. I am reminded of our facilities for fright: intake of breath, a ripple, composure coming to rest. In the photograph I have taken of the animal, I see a speck of blue in its iris. Everything else is gray; only color interferes with the consistency. The rat is gazing upward. It will never stop. I will always remember this, the instant that asks for fixation. Images oppose our departure. They pull us back into recollection, the reality beyond processed film. But neither memory nor captured scene is authentic. Even the word copy is resemblance, and this has been written about. The cage is unlocked: the rat falls out. The bucket is tipped: the water spills over. Repetition is hardly exact but we see it despite, and what we see is what lasts for us. One evening I step on our flypaper by accident. For days, my feet stick to the floor with each step, my shoes resist slight movements. I forget to clear the imprints at every occasion. I wonder if this is deliberate. 


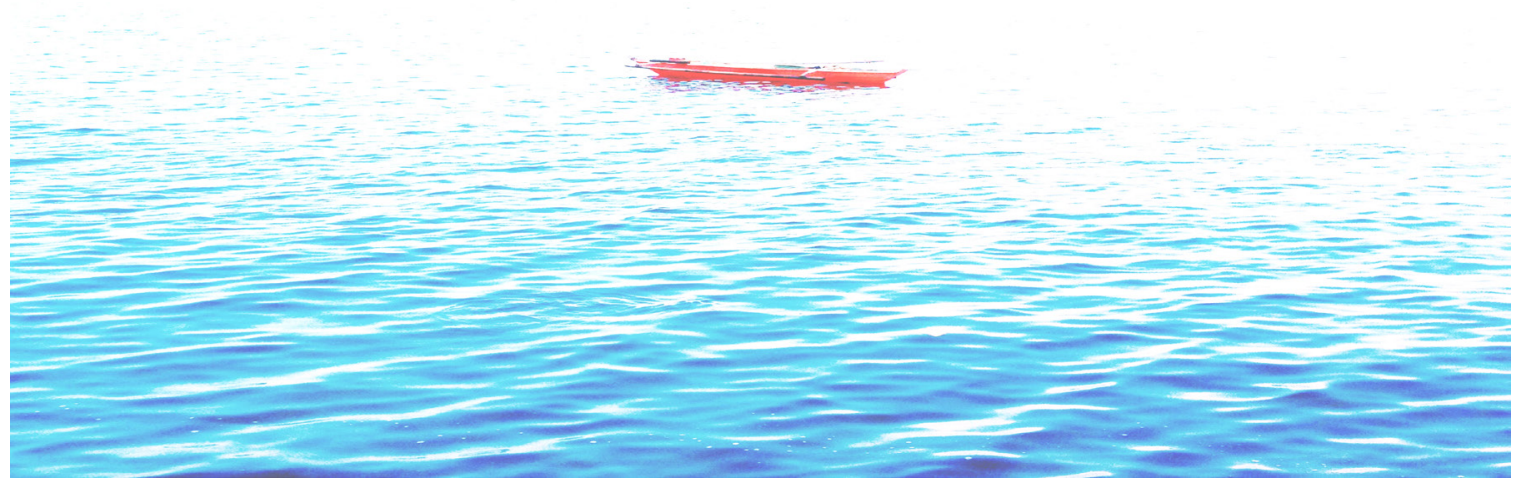

Kritika Kultura 26 (2016): -650

(ㄷ) Ateneo de Manila University

<http://kritikakultura.ateneo.net> 
The movie is about a boy, no, older: a man, who would experience darkness constantly, his vision blocked, his mind asleep in a snap, and each time, he would travel back into himself, through tens of years, into when things were younger, into when he was just a boy. The boy knew a girl who had a brother who would harm her, and a father who would take the children to their basement, filming them in a way they didn't want to be filmed, but they agreed anyway, because he was their father and that name mattered.

The man tries, again and again, to be the boy to save the girl from all of this, goes back three times for her, until at last I have to stop watching him because I'm being shuffled into the car and we're driving to the hospital and they're telling me to calm down, calm down, and all the while I'm thinking about how this would look like in a film while also thinking what is happening to me and why can't I breathe and won't I be too boring as a lead character and maybe the critics would hate me, would hate all of it because I relied too much on verisimilitude.

At home, the credits roll and I'm not there to see them. I think of how foreshadowing is a verb. 


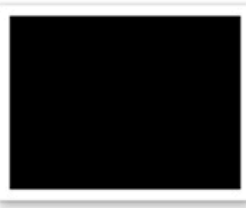

IMG10017.jpg

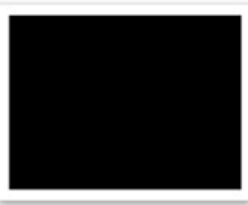

IMG10021.jpg

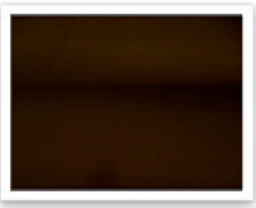

IMG10018.jpg

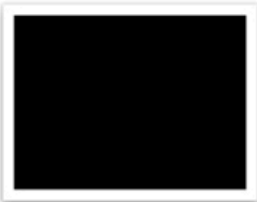

IMG10022.jpg

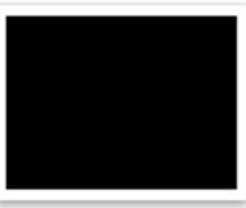

IMG10019.jpg

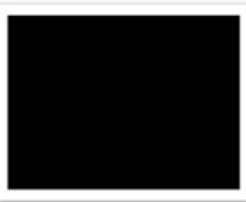

IMG10023.jpg

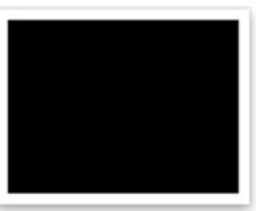

IMG10020.jpg

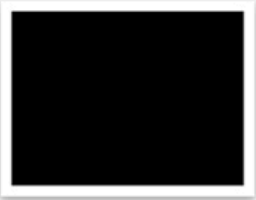

IMG10024.jpg

Your father has taken a series of photographs from the inside of his pocket. He asks you to erase them but you don't, believing that this accident of black and light is significant. You tend to generate patterns when faced with chance: what comes next or what could, like predicting the aftermath of a game, or a boxing match you know nothing about. Already you have a sense of keeping, though not a sense of why. Look at the pictures, think about the shapes of objects gone in the dark - the grooves of keys, the curves of their keychain: going as the word formless gains form. Begin to want that sense of fluidity. Take one more shot from your own pocket, click, save it for yourself and call the collection:

"Photos your father has taken from the inside of his pocket"

as if you didn't contribute. You've assigned that distance, let yourself be a spectator: you as "you," slowed down to the second person as if the self is just subtext, a stitch overlooked on purpose. It is a lot like hearing your story told without you being a part of it. 
Your father is the kind who keeps up with the news. He listens for crimes and natural disasters, narrates them over breakfast while reading the paper. "Have you heard about-?" or "Do you know what's happening in -?" catching you off-guard, bursts, even in your wakefulness. His point: be grateful; remember what it is that you have. You have always avoided the $6 \mathrm{pm}$ bulletin. It isn't a matter of interest, but of empathy for people you can't even name. You know this from a childhood episode: a rumor of a classmate's cat dead under a car, and you, inconsolable. Like that, there is much clicking of the tongue: tsk tsk tsk. Gestures accumulate. Your father, too, is prone to inventory. He lists advancements, good ones first: robots, efforts to save the trees, dirt being turned into drink. All this is allegory, only because we insist on the construction of meaning.

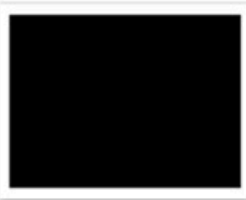

IMG10025.jpg

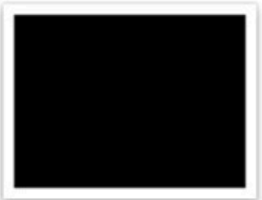

IMG10026.jpg

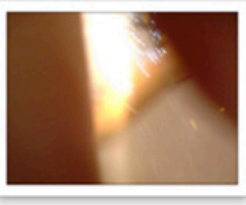

IMG10027.jpg

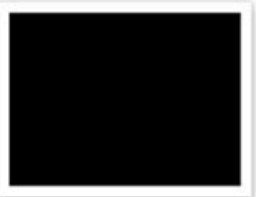

IMG10028.jpg 


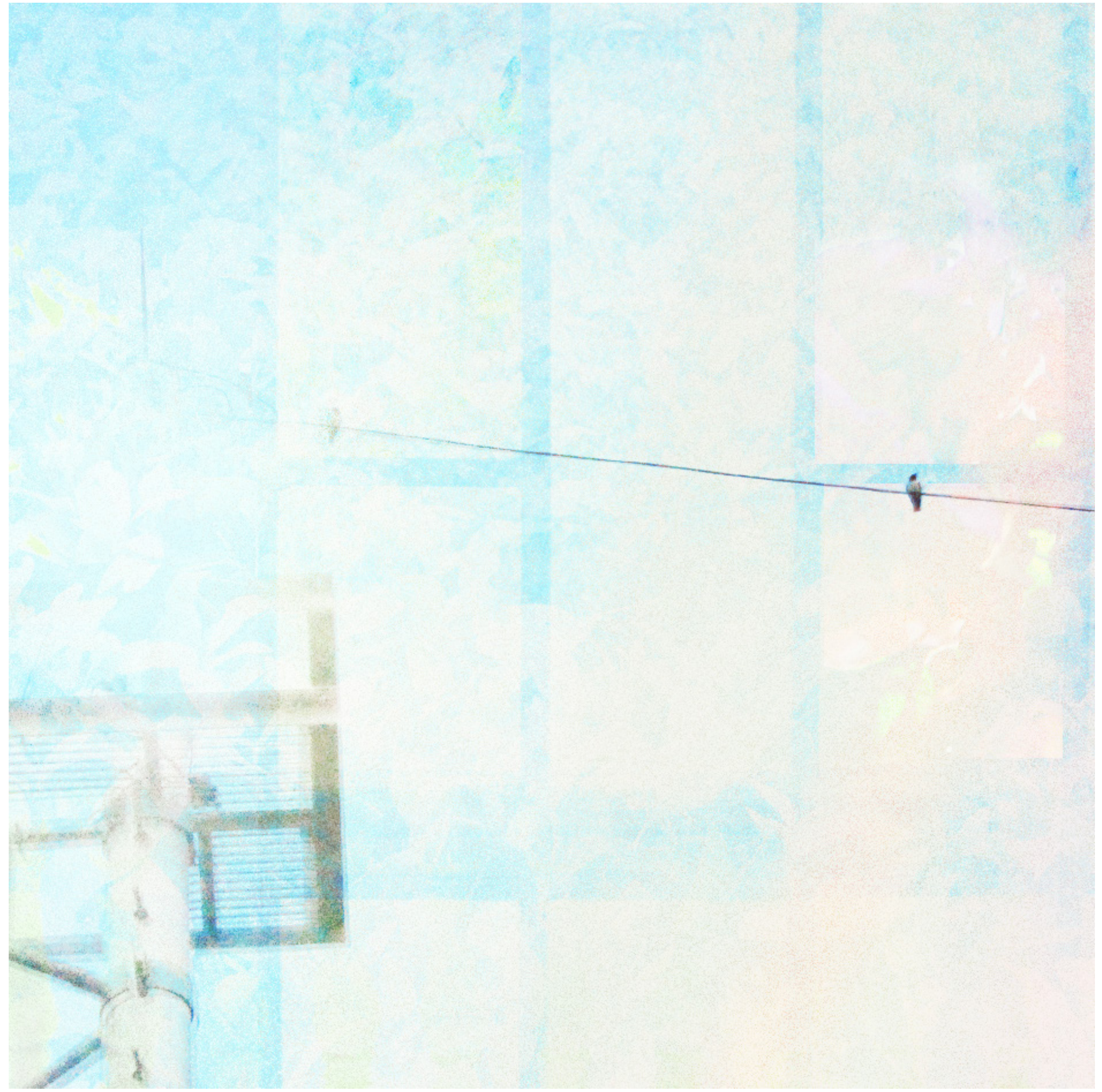

Kritika Kultura 26 (2016): -650

(ㄷ) Ateneo de Manila University

<http://kritikakultura.ateneo.net> 
For two thousand years, only women were diagnosed with hysteria. The recommended cure was pregnancy, but it took too long.

I used to sneak into my closet twice a month. It was quiet in there.

Once, I read an article where "prison" was called a "madhouse." I wondered if synonyms could've developed from metaphor.

Doctors have also tried hypnosis. Most of them were male.

At seven, I almost drowned because my inflatable animal was too slippery for my hands.

The "Cassandra Complex" is what you have when you have an illness they think you made up.

Water massages were also used on the uterus. But this is the $21^{\text {st }}$ century.

I once believed that small people lived inside our television set. They didn't want to be let out anymore, because acceptance is the final stage of grief.

OK backwards is KO. Now either way it's just $K$.

"Vapors" was considered to be the female equivalent of the melancholy found in men. Melancholia is one of Hippocrates' "humors," the study of which is called "humorism."

I've been looking for stories that "resonate" because I can't have all my details.

A physician catalogued 75 pages of possible symptoms and declared the list incomplete. 
On a trip to the zoo, the tiger in the enclosure sticks out his tongue. I find this appropriate to a passing thought and take a picture.

Obscenities, for brevity of expression.

An inmate says she wants to bite her cell bars out of boredom.

I remember a party. Any party.

For a while I was fascinated with the four temperaments: phlegmatic, choleric, sanguine, melancholic, until I couldn't choose just one.

Articulation allows motion, but not all the time.

As a kid I was sure that I'd caught the sea in the seashell that I held to my ear. I turned it over and shook it but only sand fell out.

Bit of advice: not every explanation is available. 
At the beach, we interrupt the horizon, stand there and watch boats bisect sea and sky. Two objects wash up on the shore: a small wooden frame and a bottle, variations of transparency and a prompt for symbolism, emotive, two objective correlatives nudging our feet, iterations for how each thing becomes vessel for others: placemat, plate, saucer, cup / paper, margin, paragraph, sentenceas if the world was a nesting doll. Often we're presented with conditions for juxtaposition, these, which ultimately give rise to the production of idea and affect. The flat back of the frame is gone. The bottle is unlabeled. No one is there to claim what's theirs. All revelation mirrors a technique: the intrusion of an image in a train of thought, a whim like rain in the summer, an irregularity

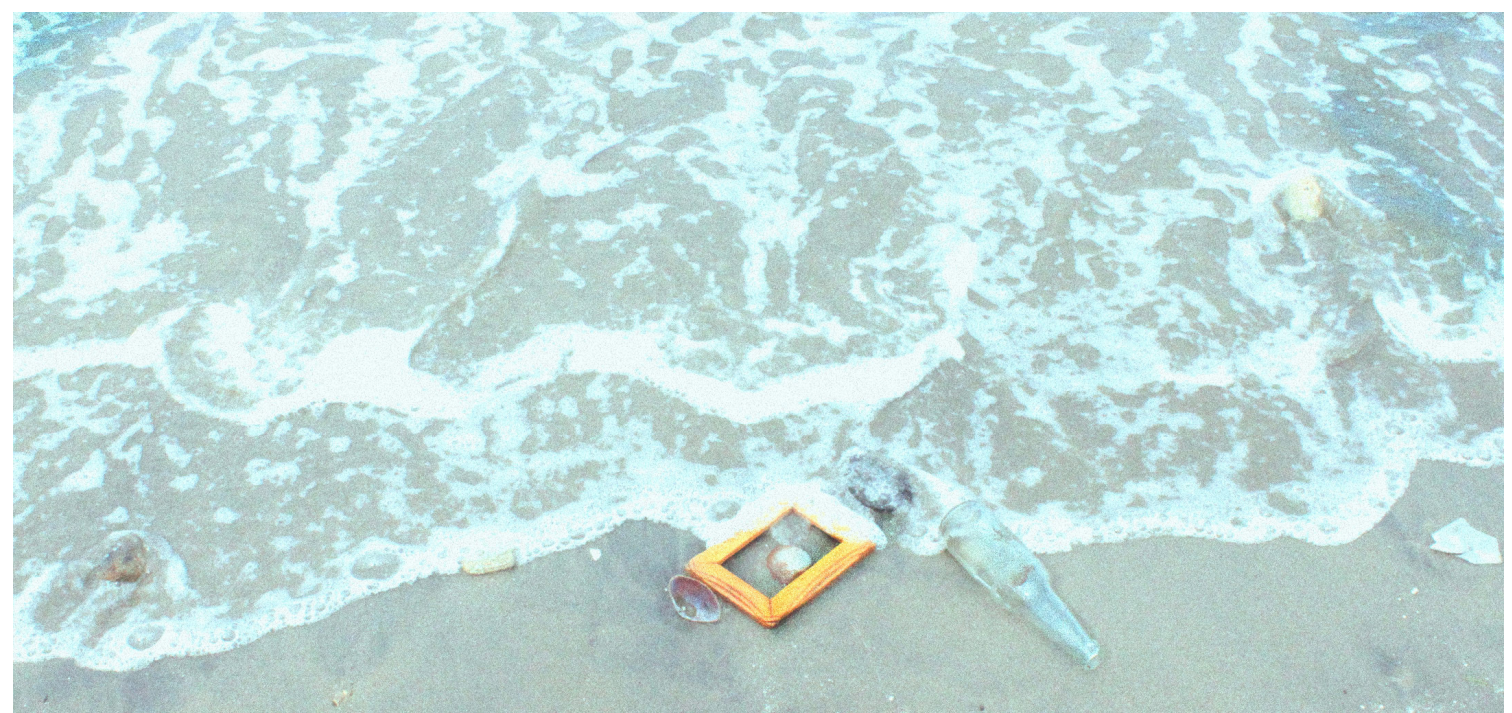

we've already grown used to. I pick up the frame and bring it home. I throw the bottle back into the deep, leaving it to find its own order. To array is to direct, to put things into place, which is to say we've been burdened by material. I brush excess sand off the edge of the wood, position it on my shelf. When I look at it I see a fragment of the wall, and picture everything else it belongs to. 


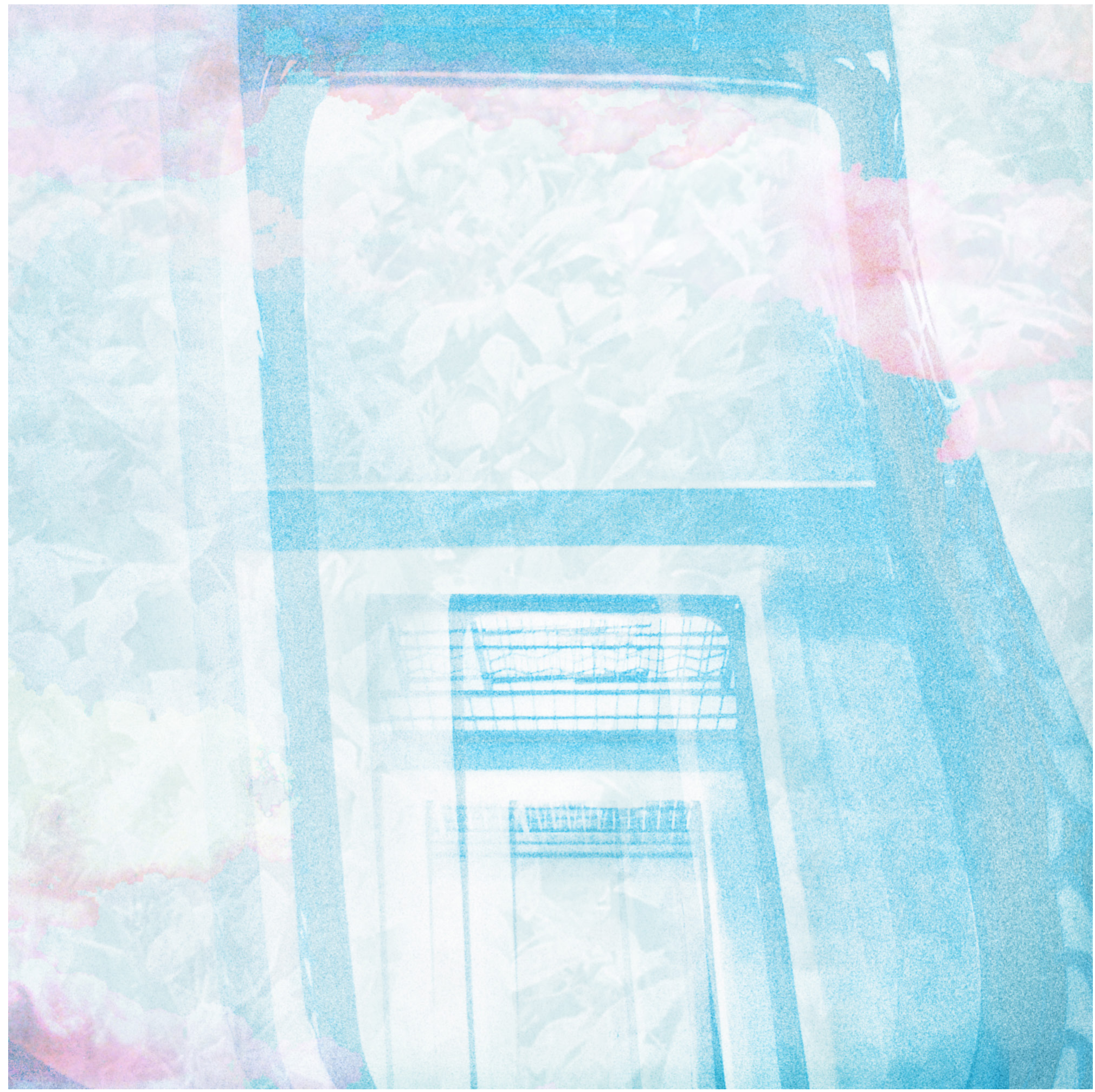

Kritika Kultura 26 (2016): -650

(C) Ateneo de Manila University

<http://kritikakultura.ateneo.net> 
The girl is made to stand in front of the class. She is told to act out a scene from a film - any film. She takes her time. She takes a breath. She chooses to perform a single line, but one from two panels in a comic strip. She imagines herself illustrated, as ink, thinks every eye is reading her twodimensional face. Quickly she veers off the script and pretends to be a mime pushing up a ceiling. Someone yawns, looks out the door. The teacher claps just to say it's over.

(It's automatic, how our own narratives glide over those of others.) 

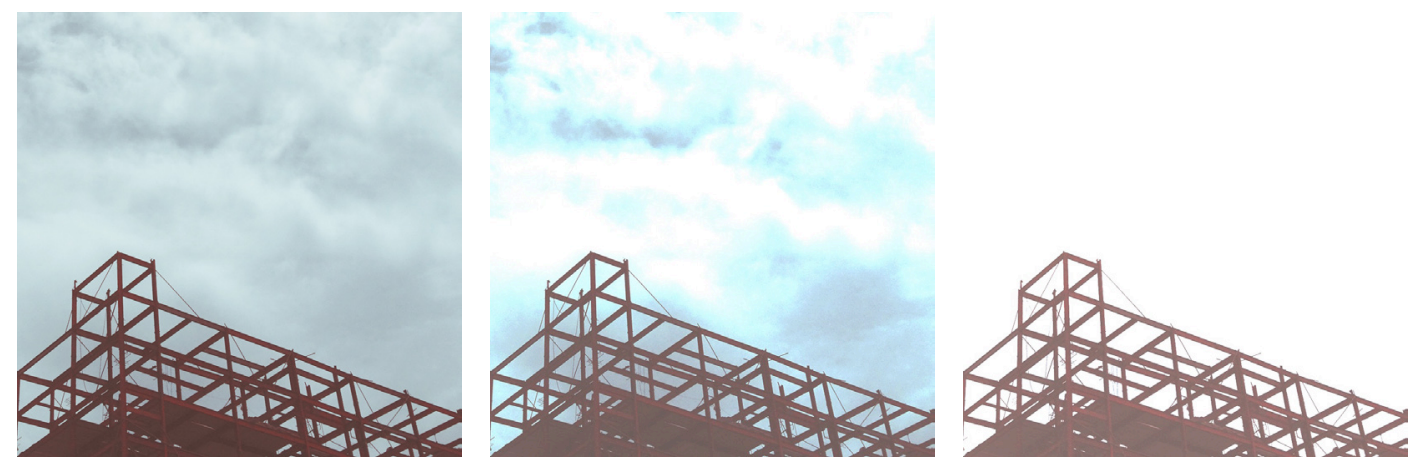

Kritika Kultura 26 (2016): -650

(c) Ateneo de Manila University

<http://kritikakultura.ateneo.net> 
A village in Tanzania was seized by a wave of laughter in 1962. It started with three girls until it spread beyond their school, the sound and sensation traveling from person to person, relentless for eighteen months.

I think: "fits," as if the body suits convulsions, and in the veins, a delight at contradiction and symmetry: we split words as if we don't have enough of them; how even in a joke, we can mean one thing, when we mean to mean another.

The Dancing Plague of 1518 began when a woman danced fervently on a Strasbourg street. Thirty-four more joined in that week and in a month, 400 others. Most of them ended up dead: the only way their bodies would stop.

Grace is a controlled movement. I consider this as I sweep dust off the floor, listening to the sway. I become immersed in the rhythm and hit a vase. It quivers and almost topples over, but finds its balance soon, calm in its awareness of pause.

In 2006, more than 300 students from different Portuguese schools were afflicted with symptoms of the same virus. All of them had rashes, suffered labored breathing, and underwent spells of dizziness. All of them had seen it on TV the day before, depicted on the teenage soap opera Morangos com Açúcar.

Among friends, the question one night was: if you could be anyone else, who would you choose to be? All answers were based on what was seen or heard, what was then known. It lay in the quality of narrative, not actual nerve. 

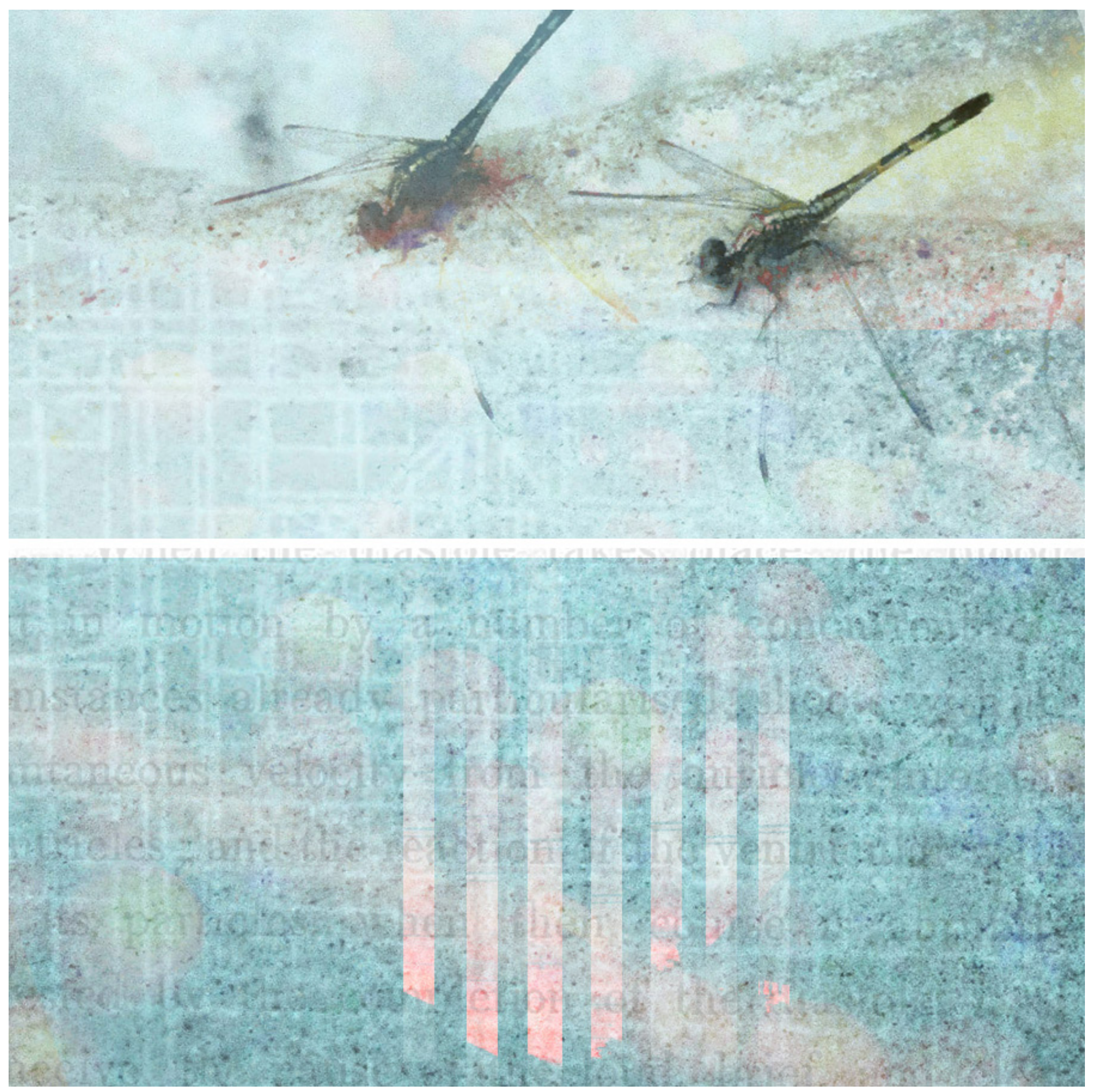

Kritika Kultura 26 (2016): -650

(c) Ateneo de Manila University

<http://kritikakultura.ateneo.net> 
The best place to hide is in the bend of the neck. The best thing to hide is the face. I sleep better under blankets. I don't like to swim. Most days I feel like an old TV show: my episodes are over but there's hope for return. Hope is not the word for this. Maybe "inevitability," and that won't always attract an audience. In a clinic, a picture of six faces acts as a scale for pain. It is a diagram meant for children. "Face 5 hurts as much as you can imagine, although the individual does not have to be crying to feel this bad." I am walking home alone when a man in a truck yells at me to take off my clothes. We don't always know what's worse. My mother forgets what she's already told me: how she stood inside an elevator when the power went out. She didn't scream; she just waited. She must understand what I've been talking about, even when I don't. Repetition has its reasons. The body, too. There are millions of cells in a single slice of skin and more in this negative space. I've only been in a cave once. In the dark, I stepped on someone's hand. I heard him curse, thought of sound as measure, music as fence. I use it all the time as if I knew what to protect. One night my mother saw me rushing towards a wall. I faced her and thought my feet had ghosts. Then: a crash, like someone sneaking in and failing. The body is possessed in parts. We don't always know what's worse. I'm told that I fell off my crib as a baby; that the mole on my sole means goodbye. We don't always know what's true. When my mother couldn't sleep, I said: find your happy place. Hers is vastness, the field she grew up in; mine is an igloo I haven't even seen. "Relationships are often the highest cause of anxiety," my doctor declares. I stay inside for days. I laugh it all off later, until it recurs. Not everything is a longing for a womb or a paragraph. I hear my friends obsess over oven-baked deaths. They must not know what it feels like, being better cooks than I am. I've been called boring before and I thought: "Give me a shovel." The problem is that we're surrounded by signs we can't always use. 


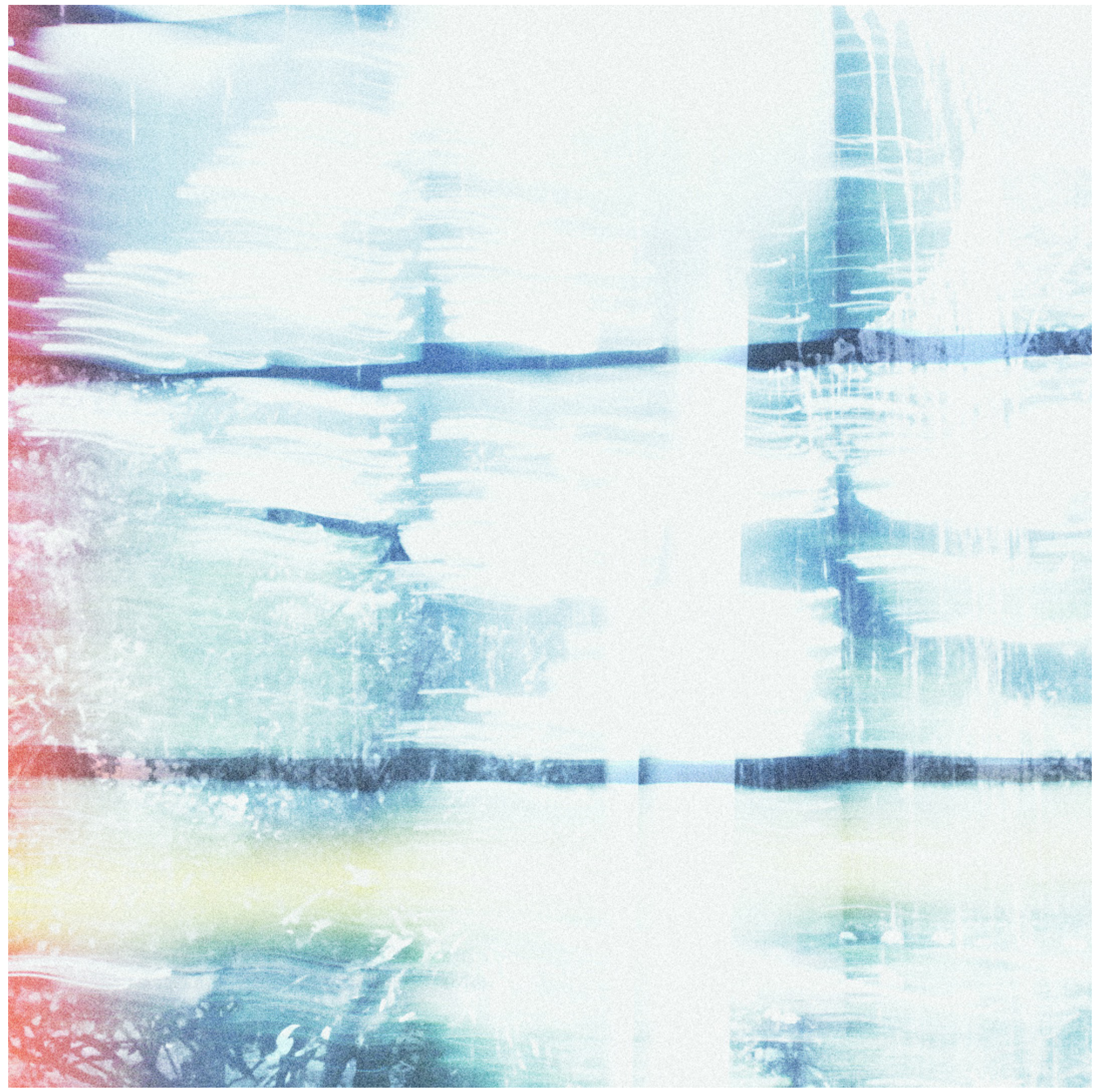

Kritika Kultura 26 (2016): -650

(c) Ateneo de Manila University

<http://kritikakultura.ateneo.net> 
In the cartoon musical Hercules, this situation appears split: as two horned imps, minions of Hades in purple and teal, repeatedly injured to provide comic relief. Neither can be trusted, really, nor have been particularly funny.

In Greek mythology, Deimos and Phobos are the twin sons of Ares and Aphrodite. One represents dread and terror. The other personifies panic and retreat. Both are gods of the fear of loss. Both are moons of Mars but look nothing alike: the latter is darker and rounder, the former pale and misshapen, like a pebble or a cloud.

In the animated film Wonder Woman, Deimos is sent to slay the titular character. She defeats him in battle, lassoes him up. She questions him about the whereabouts of his father but eventually he kills himself, scared of telling her the truth and exhibiting the potential for irony.

In an artifact found at the British Museum, Phobos is seen as a floor mosaic. He is depicted with a golden mane, his expression livid and his mouth in a toothless roar. If you cover his eyebrows, he looks stunned, as if he can't quite believe how he got there.

In psychology, the name is the source for the word phobia, where often the sufferer is dismissed as irrational.

The adjective "irrational" has also been used to refer to numbers, because our minds are prone to feats of projection. 
You're trying to recall how to record music from the radio. The clear cassette all set and ready, the dial tuned in to an FM station. It's your favorite, the one that calls itself home, the one that no longer exists. You were waiting for a song. You're not certain which. But you remember being poised to push the red button: REC, which lets you have the music all to yourself, in the form of a looping tape in a plastic box on the palm of your hand.

It was a popular song, you're sure, because your body revisits the expectation of airtime. It had been playing for days, requested over and over by people from the city and farther. You didn't know them but were grateful: how they pleaded on your behalf without knowing it, how you plead to them in silence when they don't speak.

The rest of your family is watching a game of chance on TV: a million in a suitcase, the odds twenty to one. You hear them from the next room, cheering. You believe that you have a weak grasp of luck, that there are games you just can't win. There are games that you can though, but what you do with the prize is the bigger decision. Say, your genes: black hair, pale skin, eyes that are only brown if you stare at them long enough. You've put yourself under observation; you studied you like chaos theory. Now you wonder if this lottery of particles is behind the beating too, the winning reason for the sound that won't give you quiet.

When the song does play, it's your finger that determines its beginning and end. Sometimes the voice of the DJ sneaks in, other times it's a commercial. It's coincidental: the catch of static before a song and after, the signal for you to seize your hymn. You practice this skill, collect even the commentary, but also set aside your allowance for CDs.

The contestant on TV has lost a lot of money, though all of it is theoretical. There's no cash on the table, not even in the suitcases. They're all just numbers and commas, arranged into the idea of a thing. You never even see it when they win. Think: tangibility is necessary for safety. We hold, we carry, for absence seeks response.

These days you've found cause for the noise that seems built inside you: disagreements with a boy, the temper of a parent. Maybe you need something to blame. Outside, a woman is screaming orders. Her voice overlaps with the alarm of an ambulance. Its siren escorts the tempo of some hammer on a nail. Already you've composed histories for each instance, but you've long discovered that songs just play, even without anyone asking for them. 


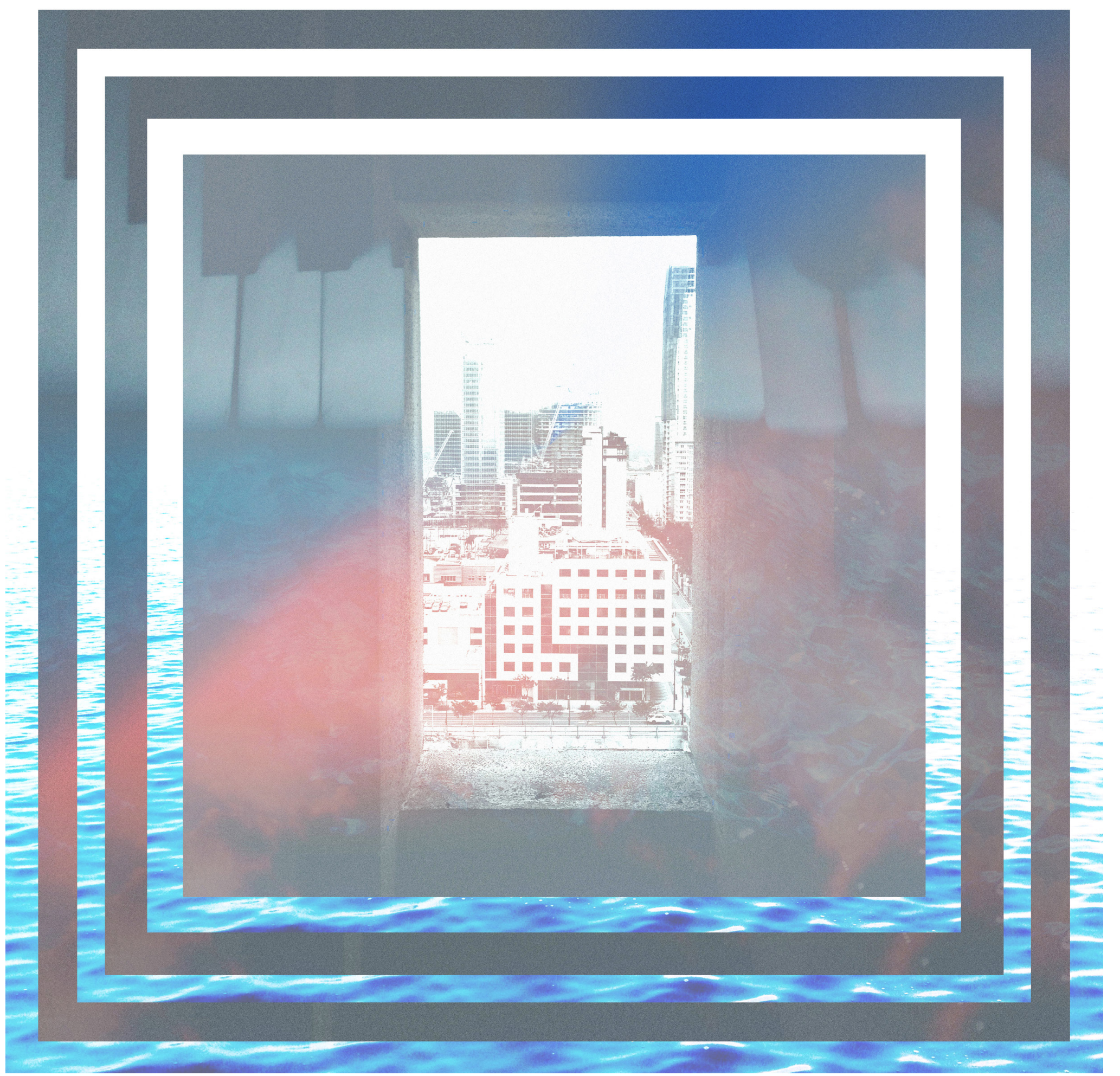

Kritika Kultura 26 (2016): -650

(ㄷ) Ateneo de Manila University

<http://kritikakultura.ateneo.net> 
This morning I return to water: the bathroom, the door, the lock: damp: on one side of the shower curtain: a pail: full:

I write about this over and over because I still don't have its reasons. I list the symptoms to learn the cause, trace the effects to draw its center, note what comes after for what came before: the results recorded and penned, because what is art but containment. There's a story that Edvard Munch painted his panic into The Scream. Tesla turned his into science; Emma Stone baked cakes. Here, I try to talk about my heart, but also I think no. I want its beats, but want them slower. I want to stop it from feeling like it's running from something, because I am done with pursuit. In one of my dreams I break a faucet and cause an overflow of rain. I can't recall how that dream ends, but let's say there was slippage and vapor. Let's say the faucet runs out of content. This is what I know of inventions: sometimes they are non-material. Sometimes I can be fine.

There is no space in the closet anymore: the boxes: stacked, the clothes: more than they used to be: dust, objects: swept away/in:

I once read a description of related conditions. I remember it because it said: imagine your brain as a filing cabinet of every thought you've ever had. I didn't read it through to the end, but I pictured all my drawers flung open, my thoughts shaken into flight and then falling. They told me it's different for everyone, like when someone said: If you want to write about love, don't mention the word but show it: a mother at work to feed her son, a couple's conversation over the phone: hi, hello. I'm not writing about love. But I could be writing about Stendhal's nerves lost in Giotto's frescoes, or a secret strain of Lisztomania, except I have it backwards and the hysterics come first. Similarities are devised all the time. On a manuscript from the $13^{\text {th }}$ century, the heart was mistaken for a fig leaf. But the fig leaf could've been mistaken for a heart too. Maybe I have foliage inside me, and that explains the rustle.

The bath mat leaves marks on my knees: small circles around a bigger circle: creased by my skin: covering my shoulders, neck, face: salt/water: in my hair: in tangles: in wires: lines: 